\title{
Green economy: waste management and recycling methods
}

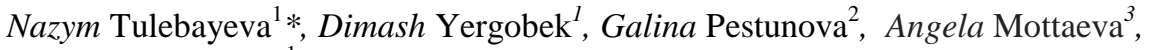 \\ Zhansaya Sapakova ${ }^{1}$ \\ ${ }^{1}$ Al-Farabi Kazakh National University, 050040 Almaty, Kazakhstan \\ ${ }^{2}$ Serikbayev East-Kazakhstan State Technical University, 070004, Ust-Kamenogorsk, \\ Kazakhstan \\ ${ }^{3}$ Moscow Region State University, Radio str, 10A, 105005, Moscow, Russia
}

\begin{abstract}
With population growth, huge waste is generated every day. Widely used plastics, advanced technology and other materialistic things. This has led to different characteristics of the waste, which has become a difficult problem for the management and disposal of household waste. The article addresses food safety issues. The main objective of the study is to review the implementation of the program for the disposal and disposal of waste. The problem of partial utilization of household waste is relevant, first of all, from the point of view of negative environmental impact.
\end{abstract}

Keywords: green economy, ecology, consumer food waste, recycling

\section{Introduction}

Green economy - an economy in which income and employment growth are driven by public and private investments that reduce carbon emissions and pollution, increase energy and resource efficiency and prevent the loss of biodiversity and ecosystem services. This will require substantial increases in investment in sectors that build on and contribute to the Earth's natural capital or reduce environmental scarcity and environmental risks. These sectors include renewable energy, low-carbon transport, energy-efficient buildings, clean technologies, improved waste management, improved freshwater supply, sustainable agriculture, forestry, and sustainable fisheries, supported by national policy reforms and international policy and market infrastructure development [1]. Of the environmental problems, food waste is an estimated serious global problem, with one third of the food produced for human consumption being lost annually worldwide [2]. Every year, more than 1.8 billion tons of waste are generated in Europe, which can be expressed as 3.5 tons per person, and which consists mainly of waste from households, commercial activities (e.g. shops, restaurants, hospitals), industry (e.g. pharmaceutical companies, clothing manufacturers), agriculture (e.g. slurry production), construction and demolition projects, mining and mineral extraction, and energy production. When producing such vast quantities of waste, it is vital that it be managed in a way that does not cause any harm to human

\footnotetext{
${ }^{1}$ Corresponding author: ertis_economika@mail.ru
} 
health or the environment. Waste management is seen as the collection, transportation, recovery, treatment and disposal of waste [3]. The environmental costs of these wastes are significant and can be reflected in the environmental burden and resources needed to produce food as well as in emissions associated with any food waste. Food waste is a particular problem in developed countries, where households are the main contributors to food waste. Reducing waste at the level of household consumption is critical as the environmental impact increases at each of the next stages of the food life cycle. Food waste is problematic not only because of its impact on the environment and the use of resources, which occurs mainly at the production stage, but also because of the ethos of food exhaustion in a world where food safety is improved. In recent years, many studies have focused on understanding food waste at the consumer level. Much less research has focused on retailing, even less on the causes and levels of food waste [4]. Over the years, food waste has become an acute problem: over 88 million tons of food waste are produced annually in Europe and over 1.3 billion tons worldwide. This correlates with the global loss of about $24 \%$ of all fresh water resources used for food crops, $23 \%$ of total crop area and $23 \%$ of total fertilizer use [5].

\section{Literature review}

Waste comes in many different forms, from different sources and is dumped in different ways. The overall end result is that material that is no longer used, stored or otherwise released into the natural environment and affects the overall quality of life. Some sources of waste can be measured, but the impact on the environment is not so easy to quantify. Two significant sources of waste generation are municipal solid waste and industrial hazardous waste [1, 2, 3]. Food entering the household is subject to normal household practices. Studies of these practices have shown that the likelihood that food will be wasted is affected by the way consumers plan, shop, store and cook food and the way they are guided $[4,5]$. There are different types of waste, such as industrial waste, agricultural waste, household waste, health center waste, organic waste and toxic waste [6]. These wastes are also found in various forms, such as solids, liquids and gases. The way waste is managed differs depending on the type of waste [8].

Recently, a new wave of political interest in understanding how "growth" can go hand in hand with "green" has occurred in the midst of the worst economic crisis in decades. Green growth means turning investment in the environment into an engine of economic growth. Modern waste management practices attach importance not only to the treatment of waste, but also to converting it into useful substances [13]. Large amounts of food waste from the household sector also mean high costs of collection and transportation as well as separation and treatment at waste management facilities. In addition, there is still a lack of knowledge about local waste prevention, especially about monitoring methods and how local waste management systems can be developed to stimulate waste reduction in households [16]. Waste is an expensive and sometimes unavoidable result of human activities and, if not adequately addressed, can have serious consequences for the environment and the quality of life and health of people. Waste and society are interconnected. In wealthier communities, the concepts of environmental and commodity management are also supported. As economic actors, environmentally conscious consumers in these communities may demand cleaner products from their retailers, making the relationship between service providers and environmental protection symbiotic [17].

\section{Methodology}

Today there is no common view on which of the technologies for MSW disposal is the most correct. Currently, incineration is a widespread method of waste disposal. This 
method is well used in countries with a good climate. In many European countries, thermal decontamination is one of the main methods of waste treatment, as their laws do not allow waste with organic content of more than $5 \%$ to be taken to landfills. In this connection, the last few years in the EU countries, USA and Japan there is a general tendency to expand the construction of new waste incineration plants and the reconstruction of existing ones with the production of power plants using alternative fuel - MSW. The total production of solid domestic waste in 2017 was 267.8 million tons of MSW, an increase of about 5.7 million tons over the amount produced in 2015. MSW produced in 2017 increased to 4.51 pounds per person per day (Diagram 1).

\section{Total MSW generated by material, $\mathbf{2 6 7 . 8}$ million tons}

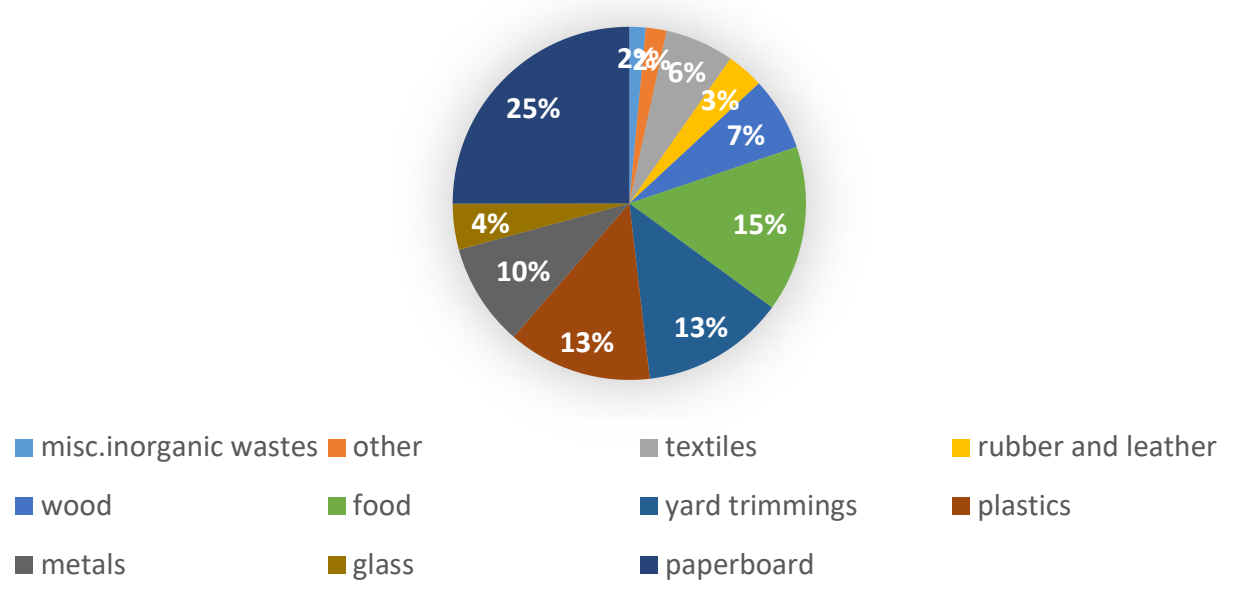

Diagram 1. Total MSW produced by the material, 2017

Paper and cardboard accounted for the largest percentage of all materials in MSW, accounting for 25 percent of total production. Paper and cardboard production fell from 84.8 million tons in 2005 to 67 million tons in 2017. The newspaper generation has been declining since 2000, and this trend is expected to continue, partly because of the reduction in page size but mainly because of the increase in news digitization. Crushing blanks were the fourth largest category of materials, estimated at 35.2 million tones, or 13.1 percent of total output, in 2017. This is comparable to 35 million tons (16.8 percent of total output) in 1990. The decline in yard output since 1990 is largely due to government legislation preventing yard waste from being disposed of in landfills, including measures to reduce sources such as backyard composting and the abandonment of grasses in the yard. In 2017, plastics production was 35.4 million tons, or 13.2 per cent. This was an increase of four million tons from 2010 to 2017 , and this was due to durable goods as well as packaging and packaging categories. Production of plastics as a percentage of total production has increased slightly over the past five years. In the same year, 2.8 million tons of selected consumer electronics were produced, representing less than 2 per cent of MSW generation. The consumer electronics selected include products such as televisions, video recorders, DVD players, camcorders, stereos, telephones and computer equipment.

According to statistics, the EU countries have the highest rates of environmentally and economically sustainable MSW processing (see Table 1). Germany takes first place in terms of recycling of food waste - 48 per cent and, accordingly, incinerates 34 per cent. Sweden and Switzerland incinerate more domestic waste - $49 \%$. For energy purposes, Denmark has the lowest indexes among European countries - $5 \%$, Belgium and 
Luxembourg - $3 \%$. In ten EU member states, less than $1 \%$ of waste is thermally treated. For example, food residue shredders are used in the USA, which are specially installed in the kitchen under the sink. The shredded waste is thus fed into the domestic sewage system and disposed of together with it. At the same time as the shredding process, the sieving process in Germany is applied, which catches the waste [6]. Many houses are equipped with these systems. These systems in the houses have their own biogas plants which dispose of the accumulated waste into biogas, which heats the water and finally generates electricity.

\begin{tabular}{|c|c|c|c|c|}
\hline $\begin{array}{c}\text { EU } \\
\text { countries }\end{array}$ & Recycling & Burning & Composting & Dumping \\
\hline Germany & 48 & 34 & 14 & 0 \\
\hline Belgium & 36 & 35 & 24 & 5 \\
\hline Sweden & 36 & 49 & 14 & 1 \\
\hline Switzerland & 34 & 49 & 4 & 62 \\
\hline Ireland & 32 & 39 & 14 & 4 \\
\hline Denmark & 34 & 48 & 16 & 32 \\
\hline France & 18 & 34 & 17 & \\
\hline
\end{tabular}

Table 1. Level of utilization of consumer waste in EU countries

All harmful and useless consumer waste or solid domestic waste is usually sent to authorized and unauthorized landfills that are near the city. Today, dumping is still the most popular way to complete waste management, even though it does not meet environmental, economic and resource requirements because waste is often a valuable source of raw materials. There are particularly important types of materials from which products can be remanufactured to make a profit. These include: paper and cardboard, glass, petroleum products, electronics, metals, wood, recycled waste, construction waste, and the like. In economic activities, recycling is the main direction.

Dumping daily waste into landfill pits or what is also called landfill is an alternative for garbage cans and is a popular method of waste disposal. It takes care of dumping waste in the ground and removing the odor from the waste. Incineration of waste at high temperatures and its transformation into residual or gaseous products is known as "incineration". Incineration should take place at temperatures of $800-1000^{\circ} \mathrm{C}$ [7]. There are several types of incinerators for waste treatment. The most common is a rotary kiln. An incinerator kiln with a rotary kiln is a cylindrical shell installed on its side with a slight slope. When the kiln rotates, the waste passes through and is incinerated. The rotary kiln incinerator is capable of receiving waste at all stages. This is the best alternative to waste bins as the waste volume here is reduced by $20-30 \%$. The process of reusing discarded materials and turning them into something new is called "Recycling". This is the third major element of the "Reduction, Reuse and Recycling" process. Recycling reduces the harmful effects of greenhouse gases and helps conserve resources for the future. Composting: When organic waste is stored in a pit for a long period of time, the microbes begin to decompose the waste. If compost is rich in nutrients, it becomes the best manure for plants [8]. According to EU policy, landfilling is considered as a last resort and should only be used if all other options have been exhausted, i.e. only materials that cannot be prevented, reused, recycled or otherwise treated should be filled.

In general, the main ways of recycling domestic waste in the system of consumer waste management are shown in Figure 1. 


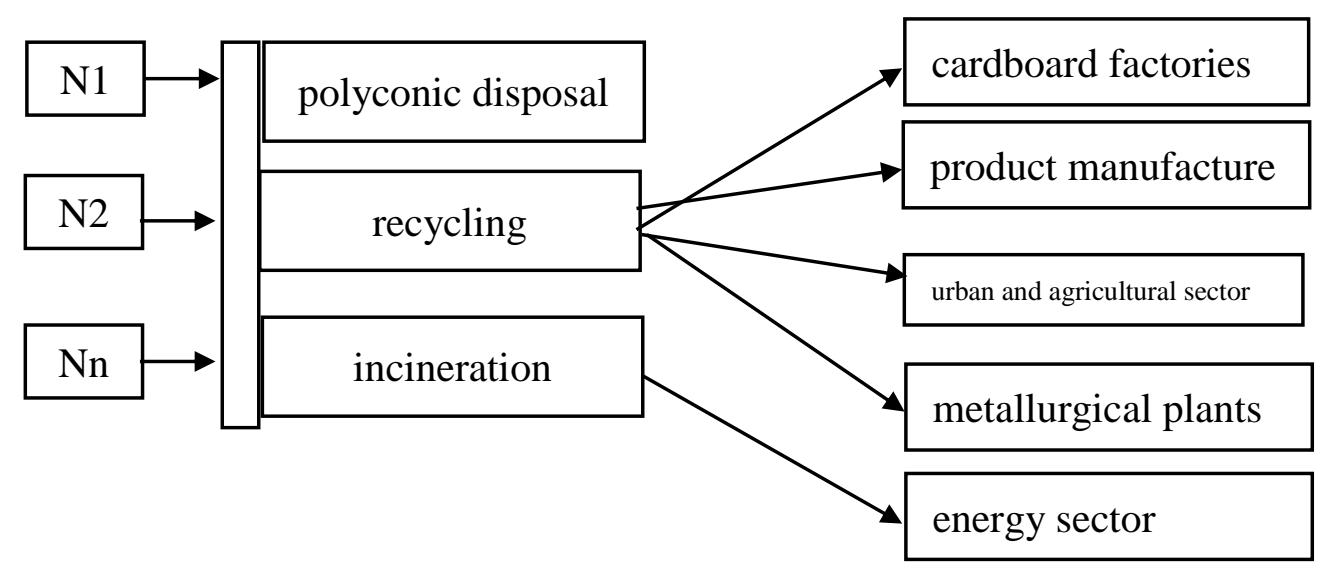

Fig.1. Main methods of disposal (N1-Nn repeaters of consumption waste)

There are various advantages of waste management [9]. Some of them are below:

Unpleasant odor reduction - waste produces a lot of unpleasant odor that is harmful to the environment. In addition, unpleasant smells are responsible for various diseases in children. As a result, it inhibits their growth. In this way, waste disposal effectively eliminates all these problems.

Reduces pollution - waste is the main cause of environmental degradation. For example, waste from industry and households pollutes our rivers. Therefore, waste management is important. So that the environment is not polluted. It also improves the hygiene of the city, so that people can have a better environment to live in.

Reduces waste production. Product recycling helps reduce waste. It also generates new products that are useful again. In addition, recycling reduces the use of new products. In this way, companies will reduce their productivity.

This creates jobs. The waste management system needs employees. These employees can perform various jobs from collection to recycling. Therefore, it creates opportunities for people who do not have jobs. Moreover, it will help them to contribute to the development of society.

It generates energy. Many wastes can be used to generate energy. For example, some products can generate heat from incineration. In addition, some organic products are useful in fertilizers. Therefore, it can increase soil fertility [10].

The introduction of a landfill tax is also an effective way to stimulate recycling in regions (or countries). These measures will only be affected if the market share of illegal dumping and extraction of natural aggregates is small. In Europe, landfills are taxed in many countries for up to 50 euros/t. In the UK, natural aggregates are subject to progressive taxation [11].

\section{Discussion}

A green economy leads to improved human well-being and social justice, while at the same time significantly reducing environmental stress and ecological deficit. This can be achieved if a change in people's culture supports sound, effective government regulation and economic incentives [12]. Safe waste disposal is a large and complex process that requires a large area, special conditions, financing and other components. Waste management is very important for maintaining the health of living beings as well as for 
creating a strong environment for future generations [13]. Waste management helps to reduce pollution, and by adapting to effective waste management practices, emissions of gases such as carbon dioxide and methane from waste can be significantly reduced. It also helps to prevent infectious diseases [14].

Table 2. SWOT analysis of waste management system

\begin{tabular}{|c|c|}
\hline Strengths & Weaknesses \\
\hline 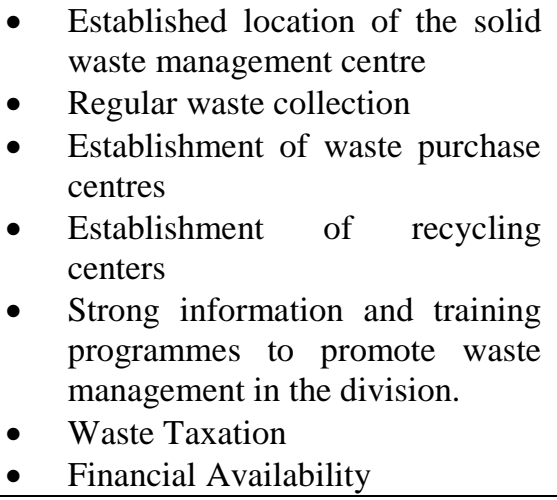 & 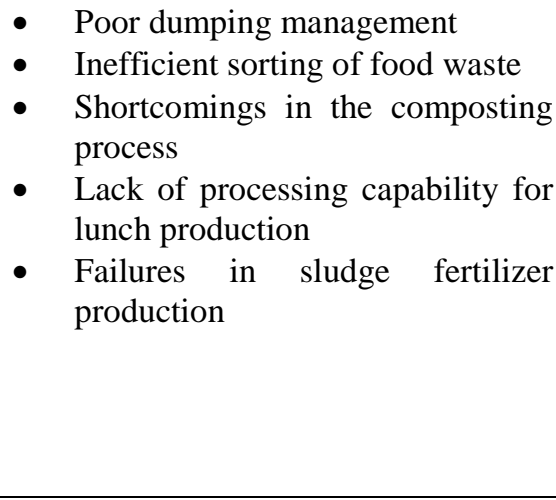 \\
\hline Opportunities & Threats \\
\hline $\begin{array}{l}\text { - Installation of a biogas plant in a } \\
\text { solid waste management center } \\
\text { Receiving external support from } \\
\text { government and industry } \\
\text { associations } \\
\text { Five waste separation bins are } \\
\text { presented } \\
\text { Application of new technologies } \\
\text { for MSW processing }\end{array}$ & $\begin{array}{l}\text { - Insufficient attention to promote } \\
\text { environmental research } \\
\text { - Invalidity of compost } \\
\text { standardization } \\
\text { - Filtrate poisoning }\end{array}$ \\
\hline
\end{tabular}

Solid domestic waste is the most common waste stream and is produced by millions of people. Major financial and logistical resources are required for its collection, recycling and final disposal. Industrial waste tends to have a greater tonnage than municipal solid waste, but is managed by relatively small and specific sectors of society. Environmentally appropriate waste management practices are important to prevent harmful effects such as the effects of toxic/hazardous waste, greenhouse gas emissions, water pollution, air pollution and noise/visual impacts (recycling/disposal facilities). Incinerators provide an effective means to reduce the mass of municipal waste, but it is important that they do not emit harmful gases, compounds and particles. Although incineration remains one of the most effective methods of organic waste management, its use has always been a subject of discussion and sometimes resistance. This is mainly due to public fear of the hazardous emissions from the incineration plant chimneys settling in surrounding communities.

There is a need to further develop more comprehensive tools for sustainable waste sustainability, including environmental, social and economic aspects. Traditional recycling technologies are very simple, resulting in rather heterogeneous products. Even when processing pure concrete, the aggregate produced does not have the same productivity as primary concrete. More sophisticated recycling technologies are still needed to produce higher quality secondary aggregates for each fractions of mineral building waste. In many 
parts of the world, the high cost of natural aggregates and the cost of landfill increases the economic viability of such processes.

Some of the proposals to eradicate the problem of household waste faced by people:

- The Government should consider all factors responsible for pollution and give priority to effective compliance with environmental laws and regulations.

- There should be a concerted effort by the Government to raise public awareness of the importance of cleanliness and environmental protection through the media, and to organize information camps at the local level.

- People should be trained to store waste at the source, dispose of waste as directed by local authorities and participate effectively in local authorities' efforts to keep cities clean.

- People should develop the habit of storing waste at the source in their own homes and dispose of such waste only in the municipal system.

- There should be a separate waste management policy through central government, and it should allocate a separate budget and work through effective institutional mechanisms at the local level [15].

Food production requires water. In the United States, food waste accounts for 25 per cent of the country's water use. Disposing of food is like leaving a tap in the country where it was produced, and an increasing number of areas suffer from water shortages.

There are several shortcomings in waste management:

1. Finance: Waste management in general may require a lot of human effort and technology to be successful. There is a need to plan and implement many waste management processes and activities. In addition, many types of waste need to be managed and there is a need for different waste management methods for different types of waste; this means higher costs of waste management.

2. Workers' health: Waste management and all processes involved can lead to a number of fungal and bacterial infections and diseases by those working in the waste management sector [16].

Ineffective solid waste management practices negatively impress foreign investors and tourists. They can lead to a loss of both investment and income from these sources. In terms of physical impacts, pollution causes psychological stress and fear of health risks. The urgency of addressing and solving the problems associated with this constant and growing state of affairs is widely recognized by governments around the world. The management of such problems should include the application of scientific principles in understanding the worldviews of the communities in which management processes are to be introduced and implemented. Numerous recent changes in waste generation, such as the emergence of e-waste among others, are very relevant. However, of all types of pollution, solid waste is considered the most visible form of world-wide pollution, and most common forms of disposal can cause serious harm to the environment if not managed. Reducing the cost to local authorities of cleaning up illegal dumps is clearly a social benefit from recycling the waste generated by demolition of building structures, especially in developing countries where the level of illegal dumps is high. Recycling also creates new green jobs along the entire supply chain, starting with separation, transport and recycling activities. This can be important, especially for countries with high unemployment rates. Understanding the social forces that influence changes in waste generation can help shed light on the social and environmental aspects of waste management as a whole.

\section{Conclusion}


The concept of green economy includes ideas from many other branches of economic science and philosophy, such as postmodernism, environmental economics and economics of the environment, anti-globalism, international relations theory and many others [17]. It also encompasses energy markets, the development of natural capital (i.e., planting and managing forests that conserve soil and water supply), clean and sustainable production, environmental innovations (e.g., fuel cells, carbon capture and storage, new materials) and further development $[18,19,20]$. A green economy is an opportunity for all countries, regardless of their level of development and economic structure. However, for each country, the transition to a green economy should be based on a country-specific model and green growth should be monitored to assess policy effectiveness and development progress.

Waste management was important in today's society. Waste comes in different forms, from different sources and is dumped in different ways. The overall end result is that material that is no longer used, deposited or otherwise released into the natural environment and affects the overall quality of life. Some sources of waste can be measured, but the impact on the environment is not so easy to quantify. Two significant sources of waste generation are municipal solid waste and industrial hazardous waste. Because of the increasing population, waste generation doubles every day. The increase in waste has an impact on the lives of many people. Waste management requires appropriate methods, taking into account environmental conditions. For example, there are various methods and techniques through which waste is disposed of. Some of them are landfills, recycling, composting, etc. In addition, these methods are very useful for the disposal of waste without harming the environment. Landfills will remain the main method of MSW processing for a long time to come. The main task is to develop the existing landfills, prolong their life and reduce their harmful impact on the environment. Only in big and largest cities construction of waste processing plants with pre-sorting of MSW is efficient $[19,21,22,23]$. The main difficulty on the way to recycling is the absence in many countries of a system of separate waste collection, which is an inevitable condition for their deep processing. For successful waste management it is necessary to take into account experience, mechanisms and technologies of foreign countries. Public education is also important. Uncertainty about waste generation, waste management practices, emissions data, impact characteristics and, in particular, health risks associated with different types of waste management practices is the main reason for the extensive market failure in waste management. Thus, the future of waste management is a delicate balance between diplomacy, science, the availability of information to the public and, above all, goodwill to change the situation.

\section{References:}

1. Ahmed, E. H. M. In The Economy of Green Cities (pp. 45-56). Springer, Dordrecht. (2013).

2. Gustavsson, J., Cederberg, C., Sonesson, U., van Otterdijk, R., \&Meybeck, A. Causes and Prevention, 29. (2011).

3. McElhatton, A., \& Pizzuto, A. Waste and its rational management. In Novel technologies in food science (pp. 3-19). Springer, New York, NY. (2012).

4. Ribeiro, A. P., Rok, J., Harmsen, R., Carreón, J. R., \& Worrell, E. Food waste in an alternative food network-A case-study. Resources, Conservation and Recycling, 149, 210-219. (2019).

5. Kummu, M., De Moel, H., Porkka, M., Siebert, S., Varis, O., \& Ward, P. J. Lost food, wasted resources: Global food supply chain losses and their impacts on freshwater, cropland, and fertiliser use. Science of the total environment, 438, 477489. (2012). 
6. Tonini, D., Albizzati, P. F., \&Astrup, T. F. Waste Management, 76, 744-766. (2018).

7. Corrado, S., Caldeira, C., Eriksson, M., Hanssen, O. J., Hauser, H. E., van Holsteijn, F., ... \&Stenmarck, Å. Food waste accounting methodologies:

Challenges, opportunities, and further advancements. Global food security, 20, 93100. (2019).

8. Slorach, P. C., Jeswani, H. K., Cuéllar-Franca, R., \&Azapagic, A. Assessing the economic and environmental sustainability of household food waste management in the UK: Current situation and future scenarios. Science of The Total Environment, 135580. (2019).

9. Bräutigam, K. R., Jörissen, J., \&Priefer, C. The extent of food waste generation across EU-27: Different calculation methods and the reliability of their results. Waste Management \& Research, 32(8), 683-694. (2014).

10. Gentil, E. C., Gallo, D., \& Christensen, T. H. Environmental evaluation of municipal waste prevention. Waste management, 31(12), 2371-2379. (2011).

11. Vázquez, E. Construction and demolition waste recycling in a broader environmental perspective. In Progress of Recycling in the Built Environment (pp. 5-35). Springer, Dordrecht. (2013).

12. Albino, V. Green Economy. In Corporate Sustainability (pp. 1-25). Springer, Berlin, Heidelberg. (2013).

13. De Menna, F., Dietershagen, J., Loubiere, M., \&Vittuari, M. Life cycle costing of food waste: A review of methodological approaches. Waste Management, 73, 1-13. (2018).

14. Sheppard, P., Garcia-Garcia, G., Stone, J., \&Rahimifard, S. Journal of Cleaner Production, 247, 119608. (2020).

15. Godfray, H. C. J., \& Garnett, T. Food security and sustainable intensification. Philosophical transactions of the Royal Society B: biological sciences, 369(1639), 20120273 (2014).

16. van Geffen, L., van Herpen, E., Sijtsema, S., \& van Trijp, H. Food waste as the consequence of competing motivations, lack of opportunities, and insufficient abilities. Resources, Conservation \& Recycling: X, 5, 100026. (2020).

17. Diyar, S., Akparova, A., Toktabayev, A., \&Tyutunnikova, M. Green EconomyInnovation-based Development of Kazakhstan. Procedia-Social and Behavioral Sciences, 140, 695-699. (2014).

18. Vazquez-Brust, D. A., \& Sarkis, J. (2012). Green growth: managing the transition to sustainable economies. In Green growth: Managing the transition to a sustainable economy (pp. 1-25). Springer, Dordrecht.

19. Oskamp, S., Harrington, M. J., Edwards, T. C., Sherwood, D. L., Okuda, S. M., \& Swanson, D. C. Factors influencing household recycling behavior. Environment and behavior, 23(4), 494-519. (1991).

20. Mutanov, G.; Ziyadin, S.; Shaikh, A. 2019. Entrepreneurship and Sustainability Issues 6(4): 2136-2158. http://doi.org/10.9770/jesi.2019.6.4(41)

21. Mukhtarova, K. S., Trifilova, A. A., \& Zhidebekkyzy, A. Journal of International Studies, 9(3), 75-87. (2016).

22. Mutanov, G., Ziyadin, S. Assessment of energy system management -The case study of Kazakhstan. /E3S Web of Conferences -2019-135,04056 (2019)

23. Ziyadin, S., Malayev, K., Yessenova, G., Beyzhanova, A. /E3S Web of Conferences 04025 (2019) 